\title{
A VASALÁSI ELJÁRÁS FELÜLETI ÉRDESSÉGRE ÉS ALAKHELYES- SÉGRE GYAKOROLT HATÁSÁNAK VIZSGÁLATA
}

\author{
Varga Gyula \\ egyetemi docens, Miskolci Egyetem, Gyártástudományi Intézet \\ 3515 Miskolc, Miskolc-Egyetemváros, e-mail: gyula.varga@uni-miskolc.hu \\ Ferencsik Viktória \\ egyetemi tanársegéd, Miskolci Egyetem, Gyártástudományi Intézet \\ 3515 Miskolc, Miskolc-Egyetemváros, e-mail: ferencsik.viktoria@uni-miskolc.hu
}

\begin{abstract}
Absztrakt
A kis környezetterhelésü, forgácsnélküli vasalási eljárás javitja a megmunkált felület integritását. A csúszó súrlódásos gyémántvasalása után eredményezödö felületi érdesség és hengerességi hiba elemzését végeztük el. Kutatómunkánk célja annak meghatározása, hogy az EN AW-2011 jelü gyengén ötvözött alumínium anyagú munkadarabok vasalása során az alkalmazott technológiai paraméterek hogyan befolyásolják a felületi érdesség (Ra) és a hengerességi hiba (CYLp, CYLv és CYLt) jellemzö értékeit.
\end{abstract}

Kulcsszavak: gyémántvasalás, felületi érdesség, alakhiba, teljes faktoriális kísérlettervezés

\section{Abstract}

The low environmental load, chip-free burnishing process improves the integrity of the machined surface. Analysis of the surface roughness and cylindrical defect resulting from the sliding friction diamond burnishing was performed. The aim of our research is to determine how the applied technological parameters affect the characteristic values of surface roughness $(R a)$ and cylindrical deviations (CYLp, CYLv and CYLt) during the burnishing of low-alloy aluminium workpieces type EN AW-2011.

Keywords: diamond burnishing, surface roughness, shape error, full factorial experimental design

\section{Bevezetés}

A mechanikai felületkezelés lényege a felületi egyenetlenségek képlékeny deformációja, amelyet a deformáló elem és a kezelendő felület közötti csúszó vagy gördülő súrlódás okoz. A kiemelkedések csúcsai képlékenyen deformálódnak, amikor a fém völgyeibe áramlanak. Ennek eredményeként az anyag felkeményedik. Ugyanakkor növekszik a deformáló elem és a kezelendő felület közötti érintkezés, a fém növeli a további deformációval szembeni ellenállását. Így a képlékeny deformáció a felület alatt egy bizonyos mélységben fejeződik be, és ezen a szint alatti csak rugalmas deformációk keletkeznek.

A mechanikai felületkezelést összehasonlítva a finomfelületi forgácsolási módszerekkel a következö előnyök tapasztalhatók:

- Nagyobb termelékenység,

- Az anyag szál elrendeződése megmarad,

- Abrazív részecskék nem maradnak a kezelt felületen,

- Kevésbé melegszik fel a kezelt felület,

- A felületi rétegben és a felület közeli alsóbb rétegekben nyomó maradó feszültség van. 
A mechanikai felületkezelés kétféle módon valósítható meg: dinamikusan és statikusan. A dinamikus módszerek (például felületszilárdító szemcseszórás, lézeres finomítás) előnye, hogy korlátozás nélkül alkalmazhatók komplex felületek kezelésére.

A statikus módszerrel a forgásszimmetrikus felületek kezelhetők. Ezeket a statikus módszereket közismerten vasalási módszereknek nevezzük. Az ezekkel a módszerekkel kapcsolatos első szabadalmak egyike 1916-ban jelent meg [1].

A statikus módszernél a következő változatok valamelyike fordulhat elő:

a) a deformáló elem egy henger vagy golyó, ami gördülő mozgással érintkezik a kezelendő felülettel;

b) a deformáló elem egy henger vagy golyó, ami csúszó súrlódással érintkezik a kezelendő felülettel;

c) a deformáló elem egy golyó, amely a kezelendő felülettel bizonyos időpontokban gördülve, más időpontokban csúszó súrlódással érintkezik a kezelendő felülettel

d) a deformáló elem egy görgő, amelynek a kezelendő felülettel való érintkezése gördülő és csúszó súrlódásos.

Számos kutató kísérletileg kimutatta, hogy a mechanikai felületkezelés növeli a felületi kopásállóságot, felületi integritást [2-4]. Kísérletileg is bebizonyították, hogy a mechanikai felületkezelés növeli a kezelt felületek korrózióállóságát [5]. A csúszó súrlódásos vasalás egy statikus mechanikai felületkezelési módszer. A módszer fő előnye, hogy egyszerü eszközökkel és szerszámokkal megvalósítható. Ha az alakító elem mesterséges vagy természetes gyémántból készül, a módszert gyémánt vasalásnak vagy csúszó súrlódásos gyémánt vasalásnak nevezik. A General Electric elöször 1962-ben vezette be a csúszó súrlódásos gyémánt vasalást a kezelt alkatrészek felületi integritásnak javítása céljából [6].

Kutatómunkánk célja annak meghatározása, hogy az enyhén ötvözött alumínium anyagú munkadarabok vasalása során az alkalmazott technológiai paraméterek hogyan befolyásolják a felületi érdesség és az alakpontosság jellemző értékeit.

\section{Az eljárás alkalmazása külső hengeres felületen}

Kutatómunkánk során külső hengeres felület gyémántszerszámos felületvasalásával, illetve az általa létrehozott hengeres felület alakhibájának, továbbá a hengeres felület érdességének változásával foglalkozunk. A kísérletek megtervezéséhez és végrehajtásához a teljes faktoriális kísérlettervet alkalmazzuk, mellyel empirikus képletek hatékonyan meghatározhatóak, továbbá, az eredményeket speciális viszonyszámok képzésével értékeljük ki.

A csúszó súrlódásos vasalás kinematikailag hasonló az esztergáláshoz, de a forgácsolószerszám éle helyett a deformáló elem gömb alakú, nyomott vége mozog a kezelendő felületen. Az eljárás képlékeny deformációt hoz létre a kezelt munkadarab felületén és a felszín alatti, felszín közeli rétegeiben (1. ábra).

A csúszó súrlódás elvén müködő vasaló szerszámok alkalmazhatók minden hagyományos és CNC vezérlésű esztergán vagy $\mathrm{CNC}$ esztergaközponton. Így a munkadarabokat, közvetlenül a forgácsoló megmunkálás után, a forgácsoló megmunkálással megegyező befogásban lehet vasalni. A csúszó súrlódásos vasalás alkalmazható külső hengeres felületek, nagy átméröjü belső hengeres felületek kezelésére, de még síkfelületek kezelésére is. A csúszó súrlódásos vasalás nagyon gazdaságosan alkalmazható tükörszerü befejező felületkezelések megvalósítására vas és színesfém munkadarab anyagok esetén. A csúszó súrlódásos vasalási folyamat elkészítésének főbb müszaki és technológiai paraméterei: a deformáló elem $\mathrm{r}$ gömbsugara, $\mathrm{mm}$; vasalóerö $\mathrm{F}, \mathrm{N}$; előtolás $\mathrm{f}, \mathrm{mm} /$ ford; vasalósebesség $\mathrm{v}, \mathrm{m} / \mathrm{min}$. További tényezők: a vasalási járatszám ,i” és a kenőanyag típusok. 


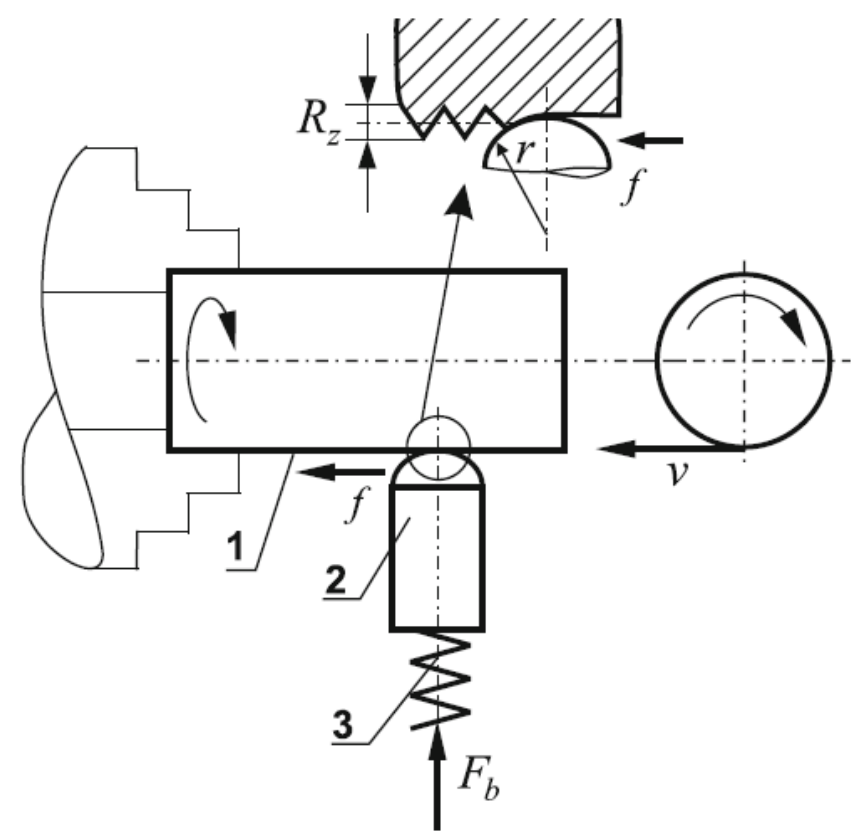

1. ábra A csúszó súrlódásos vasalás elvi vázlata [18]

(r- vasalógömb sugara; 2 - vasaló szerszám, 3 - rúgó; $\mathrm{F}_{\mathrm{b}}$ - vasaló erö; v - sebesség; f - elötolás)

\section{Kísérleti körülmények}

\subsection{A vizsgálat tárgya}

A vizsgálatokat gyengén ötvözött alumínium próbadarabokon végeztük. A gyengén ötvözött alumíniumot széles körben használják a mérnöki gyakorlat különböző területein, pl. a jármüiparban, a repülögépiparban, a háztartási készülékekben, a müszerekben stb. Az ezekből az alumíniumokból készült alkatrészek felületi rétegére vonatkozó leggyakoribb követelmények az alacsony érdesség, a precíz alakhelyesség. Ezeket a követelményeket nagyrészt a felület hideg képlékeny deformációján alapuló vasalási technológiák hatékonyan kielégítik [19], köszönhetően gyengén ötvözött alumínium próbadarabok alacsony sürüségének és jó mechanikai tulajdonságainak. Az EN AW-2011 jelü alumínium kémiai öszszetétele az 1. táblázatban található.

1. táblázat. A vizsgált alumínium ötvözet vegyi összetétele (Térfogat\%) [19]

\begin{tabular}{|c|c|c|c|c|c|c|c|c|c|c|c|}
\hline & $\mathrm{Si}$ & $\mathrm{Fe}$ & $\mathrm{Cu}$ & $\mathrm{Mn}$ & $\mathrm{Mg}$ & $\mathrm{Cr}$ & $\mathrm{Zn}$ & $\mathrm{Bi}$ & $\mathrm{Pb}$ & $\mathrm{Bi}$ & $\mathrm{Al}$ \\
\hline Min & & & 3,3 & 0,5 & 0,4 & & & 0,2 & 0,2 & 0,3 & 89,3 \\
\hline Max & 0,4 & 0,8 & 4,6 & 1 & 1,8 & 0,1 & 0,2 & 0,6 & 0,6 & 0,6 & 95,1 \\
\hline
\end{tabular}

A vasalási műveleteket simító esztergálás előzte meg, amit az $\mathrm{R}=3,5 \mathrm{~mm}$ sugarú $\mathrm{PCD}$ (mesterséges gyémánt) szerszámmal végzett vasalás követett. A különböző kísérletek során faktorként a vasalási járatszám (i), sebesség $(v)$, előtolás (f), vasalóerő $\left(F_{b}\right)$ szerepel. 


\subsection{A kísérleti paraméterek}

A továbbiakban a megvalósított több kísérletböl 2 példát közlünk. A teljes kísérlettervezés módszer alkalmazásához a kiválasztott faktorok értékeit 2 szintre (minimális, maximális) állítottuk be, melyeket a 2. táblázat összegez.

2. táblázat. Vasalási paraméterek

\begin{tabular}{|c|c|c|c|c|c|c|}
\hline \multirow{2}{*}{ Ssz. } & \multicolumn{3}{|c|}{ Vasalási paraméterek I. } & \multicolumn{3}{c|}{ Vasalási paraméterek II. } \\
\cline { 2 - 7 } & $\mathrm{i}[\varnothing]$ & $\mathrm{f}[\mathrm{mm} /$ ford] & $\mathrm{F}[\mathrm{N}]$ & $\mathrm{v}[\mathrm{m} / \mathrm{min}]$ & $\mathrm{f}[\mathrm{mm} /$ ford] & $\mathrm{F}[\mathrm{N}]$ \\
\hline 1 & 1 & 0,001 & 10 & 15 & 0,001 & 10 \\
\hline 2 & 3 & 0,001 & 10 & 30 & 0,001 & 10 \\
\hline 3 & 1 & 0,005 & 10 & 15 & 0,005 & 10 \\
\hline 4 & 3 & 0,005 & 10 & 30 & 0,005 & 10 \\
\hline 5 & 1 & 0,001 & 20 & 15 & 0,001 & 20 \\
\hline 6 & 3 & 0,001 & 20 & 30 & 0,001 & 20 \\
\hline 7 & 1 & 0,005 & 20 & 15 & 0,005 & 20 \\
\hline 8 & 3 & 0,005 & 20 & 30 & 0,005 & 20 \\
\hline
\end{tabular}

A számszerủ értékek meghatározása során korábbi elméleti és gyakorlati kutatómunkánk eredményeit vettük figyelembe.

\subsection{A jellemzők mérésének eszközei, dimenzió nélküli jellemzők}

A felületi érdesség mérését 3 ponton $120^{\circ}$-onként valósítottuk meg Altisurf 520 típusú 3D-s kromatikus érdesség mérő berendezésen.

A próbadarabok hengerességének (CYLp, CYLv és CYLt) mérését a Miskolci Egyetem Gyártástudományi Intézetben található Taylor Hobson Talyrond 365 típusú köralak- és helyzethiba vizsgáló berendezésen végeztük el. Jelen kísérletsorozatban az induktív szenzor segítségével végeztük a méréseket mind a vasalás előtt, illetve után $3 \mathrm{~mm}$-es távolságokban. A mérőgép szoftvere összesen 16 hengerességi jellemző mérőszámot határoz meg. Közülük a müködési tulajdonságokat leginkább meghatározó paramétereket határoztuk meg és hasonlítottuk össze. Ezek közé tartoznak (az ISO 12180-1 szabványban szereplö) CYLp és CYLv értékek, melyek a referencia hengerhez viszonyítva ábrázolják a felület legnagyobb eltérését kiemelkedések (peak) és völgyek (valley) formájában. A CYLt változása pedig ezen kiemelkedések és völgyek összegzett távolságát adja.

Vizsgálataink során a mért jellemzők változásának szemléletesebbé tételéhez dimenzió nélküli viszonyszámokat hoztunk létre, melyet az alábbi képletek segítségével számítottunk ki:

$$
\begin{gathered}
\rho_{X}=\frac{X_{\text {vasalt }}}{X_{\text {esztergált }}} \\
\Delta \rho_{X} \%=\left(\rho_{X}-1\right) \cdot 100 \%
\end{gathered}
$$

ahol:

$X$ lehet: $\quad X=R a ; X=C Y L p ; X=C Y L v ; X=C Y L t$

$\rho_{X} \quad$ A vizsgálati jellemző dimenzió nélküli javulási viszonyszáma

ha $X=$ Ra akkor $\rho_{X}=\rho_{\text {Ra }}$; ha $X=C Y L p$ akkor $\rho_{X}=\rho_{\text {CYLp }}$; ha $X=C Y L v$ akkor $\rho_{X}=\rho_{C Y L v}$; ha $\mathrm{X}=\mathrm{CYLt}$ akkor $\rho_{\mathrm{X}}=\rho_{\mathrm{CYL}}$;

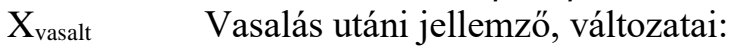

ha $X=R a$ akkor $X_{\text {vasalt }}=\mathrm{Ra}_{\text {vasalt }} ; X=C Y L p$ akkor $X_{\text {vasalt }}=C Y L p_{\text {vasalt; }}$;

ha $X=C Y L v$ akkor $X_{\text {vasalt }}=C$ YLv $_{\text {vasalt }}$; ha $X=C Y L t$ akkor $X_{\text {vasalt }}=\mathrm{CYLt}_{\text {vasalt }}$; 


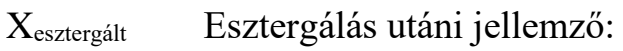

ha $X=R a$ akkor $X_{\text {esztergált }}=\mathrm{Ra}_{\text {esztergált }} ; X=C Y L p$ akkor $X_{\text {esztergált }}=C Y L p_{\text {esztergált}}$;

ha $X=C Y L v$ akkor $X_{\text {esztergalt }}=C Y L v_{\text {esztergált }}$; ha $X=C Y L t$ akkor $X_{\text {esztergált }}=C_{\text {CYLt }}$ esztergált;

$\Delta \rho_{X} \% \quad$ A javulási viszonyszám változásának százalékos értéke

ha $X=$ Ra akkor $\Delta \rho_{X} \%=\Delta \rho_{\text {Ra }} \% ; X=$ CYLp akkor $\Delta \rho_{X} \%=\Delta \rho_{\text {CYLp }} \%$;

ha $X=$ CYLv akkor $\Delta \rho_{\mathrm{X}} \%=\Delta \rho_{\mathrm{CYLv}} \%$; ha $\mathrm{X}=\mathrm{CYLt}$ akkor $\Delta \rho_{\mathrm{X}} \%=\Delta \rho_{\mathrm{CYLt}} \%$;

Ra, CYLp, CYLv és CYLt esetén a viszonyszám értéke minél nagyobb negatív szám, annál nagyobb mértékü javulás tapasztalható a vasalás következtében.

\section{Eredmények}

A mérési eredményeket és a számított javulási viszonyszámokat az I. esetre vonatkozóan a 3. táblázat, a II. esetre a 4. táblázat foglalja össze.

3. táblázat. A mért értékek és a számított viszonyszámok értékei I.

\begin{tabular}{|c|c|c|c|c|c|c|}
\hline \multirow{2}{*}{ Ssz. } & \multicolumn{2}{|c|}{$\mathbf{R a}[\mu \mathbf{m}]$} & \multirow{2}{*}{$\begin{array}{l}\Delta \rho_{\mathrm{Ra}} \\
{[\%]}\end{array}$} & \multicolumn{2}{|c|}{ CYLt $[\mu \mathrm{m}]$} & \multirow{2}{*}{$\begin{array}{c}\Delta \rho C Y L t \\
{[\%]}\end{array}$} \\
\hline & esztergált & vasalt & & esztergált & vasalt & \\
\hline 1 & 1,226 & 0,3457 & $-69,21$ & 14,32 & 14,69 & 2,58 \\
\hline 2 & 1,0118 & 1,8215 & 80,03 & 13,04 & 173,99 & 1234 \\
\hline 3 & 0,9947 & 0,3599 & $-63,82$ & 15,83 & 13,01 & $-17,81$ \\
\hline 4 & 0,9450 & 0,2516 & $-73,38$ & 13,20 & 24,11 & 82,65 \\
\hline 5 & 0,9213 & 1,2686 & 37,65 & 18,88 & 64,60 & 242,20 \\
\hline 6 & 1,0622 & 2,2249 & 109,46 & 16,41 & 201,54 & 1128 \\
\hline 7 & 1,0679 & 0,5875 & $-44,99$ & 12,36 & 23,70 & 91,75 \\
\hline 8 & 1,0741 & 1,3817 & 28,64 & 14,96 & 76,62 & 412,2 \\
\hline
\end{tabular}

4. táblázat. A mért értékek és a számitott viszonyszámok értékei II.

\begin{tabular}{|c|c|c|c|c|c|c|c|c|c|}
\hline \multirow{2}{*}{ Ssz. } & \multicolumn{2}{|c|}{ CYLp [um] } & \multirow{2}{*}{$\begin{array}{c}\Delta \rho C Y L p \\
{[\%]}\end{array}$} & \multicolumn{2}{|c|}{ CYLv $[\mu \mathrm{m}]$} & \multirow{2}{*}{$\begin{array}{c}\Delta \rho C Y L v \\
{[\%]}\end{array}$} & \multicolumn{2}{|c|}{ CYLt $[\mu \mathrm{m}]$} & \multirow{2}{*}{$\begin{array}{c}\Delta \rho C Y L t \\
{[\%]}\end{array}$} \\
\hline & esztergált & vasalt & & esztergált & vasalt & & esztergált & vasalt & \\
\hline 1 & 9,92 & 13,28 & 33,87 & 4,98 & 4,91 & $-1,41$ & 14,9 & 18,18 & 22,01 \\
\hline 2 & 4,09 & 8,97 & 119,32 & 5,70 & 8,06 & 41,40 & 9,79 & 17,03 & 73,95 \\
\hline 3 & 4,93 & 10,29 & 108,72 & 4,79 & 5,66 & 18,16 & 9,72 & 15,95 & 64,09 \\
\hline 4 & 4,42 & 5,77 & 30,54 & 3,97 & 7,24 & 82,37 & 8,39 & 13,01 & 55,07 \\
\hline 5 & 17,25 & 14,29 & $-17,16$ & 9,08 & 10,61 & 16,85 & 26,34 & 24,90 & $-5,47$ \\
\hline 6 & 7,49 & 11,05 & 47,53 & 6,58 & 6,85 & 4,10 & 14,06 & 17,90 & 27,31 \\
\hline 7 & 7,61 & 6,63 & $-12,88$ & 5,06 & 5,83 & 15,22 & 12,67 & 12,45 & $-1,74$ \\
\hline 8 & 5,51 & 7,53 & 36,66 & 5,15 & 9,65 & 87,37 & 10,67 & 17,18 & 61,16 \\
\hline
\end{tabular}

A teljes faktoriális kísérlettervezés alkalmazásával empirikus képletet (3-7) határoztunk meg a MathCAD program felhasználásával, mely számítási eredmények szemléltetését axonometrikus ábrákon végeztük (2-5. ábra). 


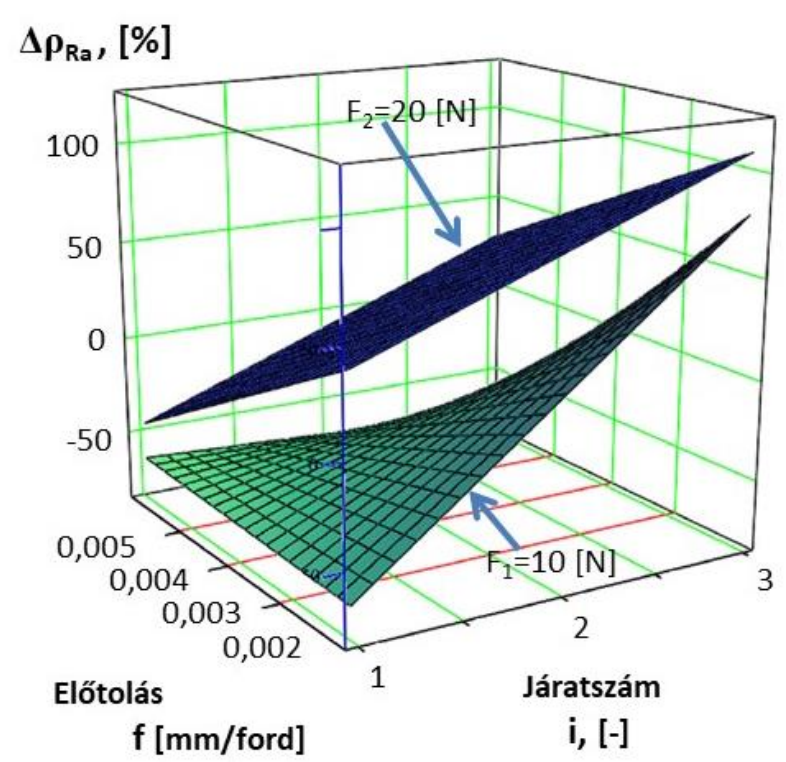

2. ábra Vasalás I.: Az Ra felületi érdesség változása

$\Delta \rho_{R a}=-352,6875+153,263 \cdot i+6,328 \cdot 10^{4} \cdot f+18,766 \cdot F-3,993 \cdot 10^{4} \cdot i \cdot f-5,879 \cdot i \cdot F-$ $-4,208 \cdot 10^{3} \cdot f \cdot F+2,008 \cdot i \cdot f \cdot F$

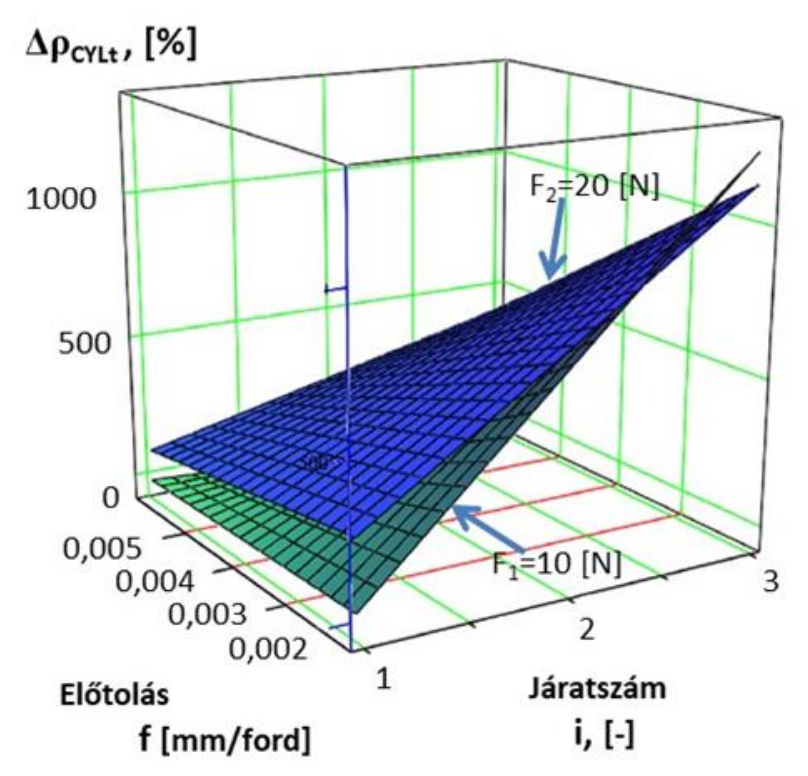

3. ábra Vasalás I.: A CYLt hengerességi hiba változása

$\Delta \rho_{C Y L_{t}}=-79.72+7.27 \cdot v+5.81 \cdot 10^{4} \cdot f+2.40 \cdot F-5.53 \cdot 10^{3} \cdot v \cdot f-0.28 \cdot v \cdot F-3.24 \cdot 10^{3} \cdot f \cdot F+$ $+151.80 \cdot v \cdot f \cdot F$ 


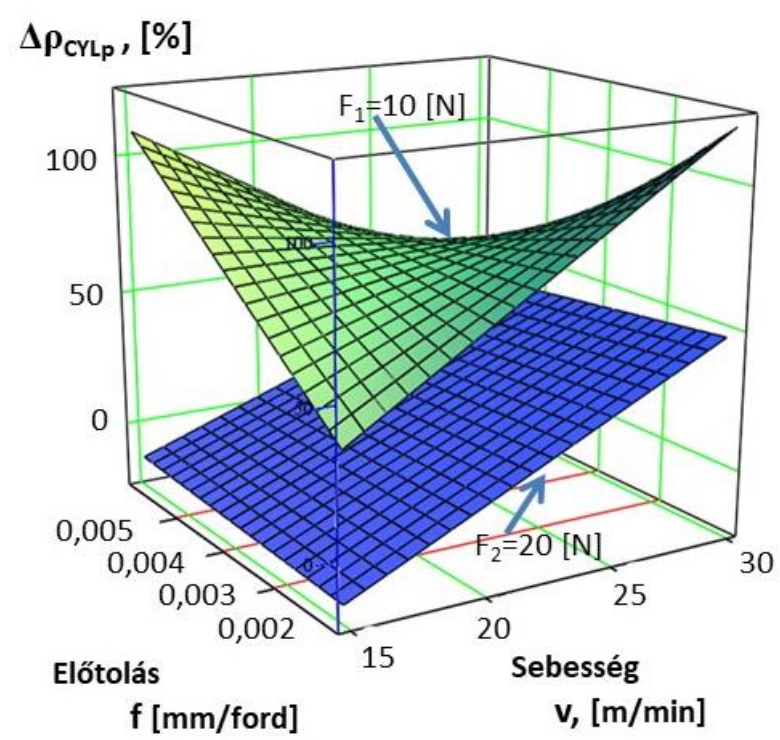

4. ábra Vasalás II.: A CYLt hengerességi hiba változása

$$
\begin{aligned}
\Delta \rho_{C Y L_{p}}= & -135.69+12.28 \cdot v+1.14 \cdot 10^{5} \cdot f+2.45 \cdot F-5.20 \cdot v \cdot f-0.39 \cdot v \cdot F--5.48 \cdot 10^{3} \cdot f \cdot F- \\
& -247.47 \cdot v \cdot f \cdot F
\end{aligned}
$$

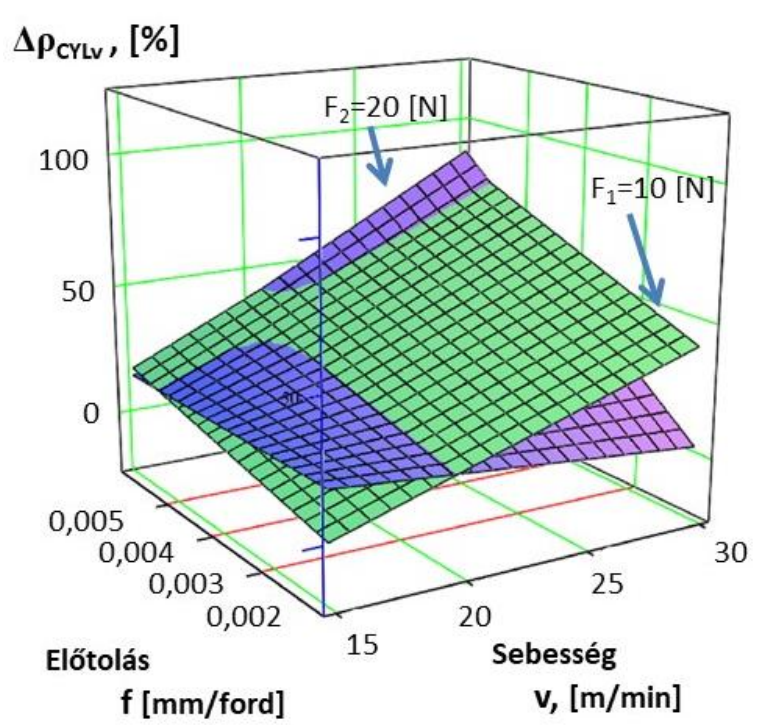

a)

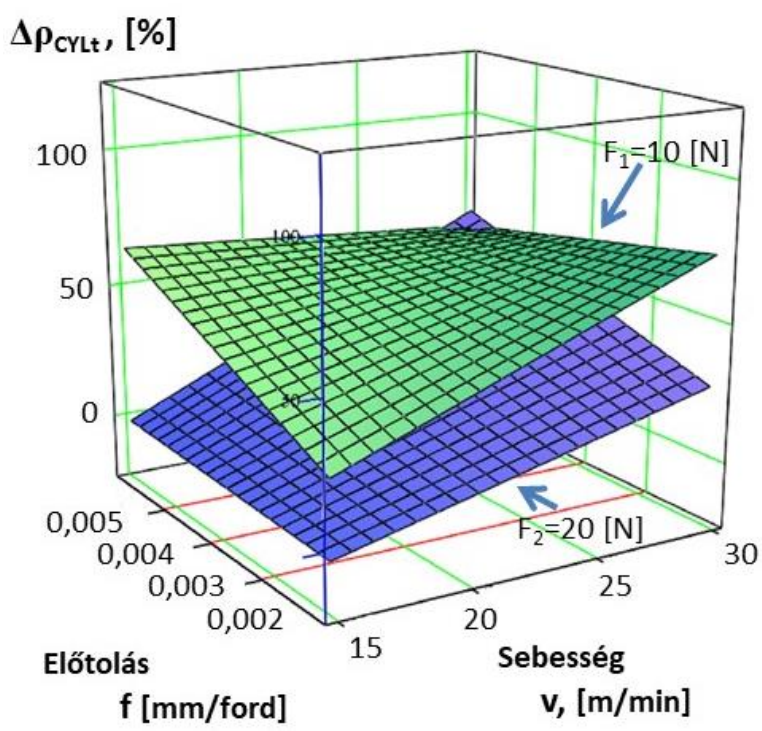

b)

5. ábra Vasalás II.: Az a) CYLv és b) CYLt hengerességi hiba változása

$$
\begin{aligned}
\Delta \rho_{C Y L_{v}}= & -138.76+7.26 \cdot v+2.07 \cdot 10^{4} \cdot f+9.49 \cdot F-701.67 \cdot v \cdot f-0.476 \cdot v \cdot F-2.12 \cdot 10^{3} \cdot f \cdot F+ \\
& +105.83 \cdot v \cdot f \cdot F \\
\Delta \rho_{C Y L_{t}}= & -79.72+7.27 \cdot v+5.81 \cdot 10^{4} \cdot f+2.40 \cdot F-5.53 \cdot 10^{3} \cdot v \cdot f-0.28 \cdot v \cdot F-3.24 \cdot 10^{3} \cdot f \cdot F+ \\
& +151.80 \cdot v \cdot f \cdot F
\end{aligned}
$$




\section{5. Összegzés és következtetések}

A csúszó súrlódásos PCD szerszámmal gyengén ötvözött alumínium anyagminőségü külső hengeres felület vasalásakor, a felületi érdességre és hengerességi alakhibára vonatkozó kísérleti eredményeinket foglaltuk össze. A teljes faktoriális kísérletterv alapján megvalósított kísérleteinknél a kísérleti paraméterek: az I. kísérletsorozatnál: a vasalási járatszám, előtolás és vasalóerő voltak, míg a II. kísérletsorozat esetén: sebesség, előtolás és vasalóerő. Kutatómunkánk célja annak meghatározása volt, hogy az enyhén ötvözött alumínium anyagú munkadarabok vasalása során az alkalmazott technológiai paraméterek hogyan befolyásolják a felületi érdesség és az alakpontosság jellemző értékeit. Az eredményeződő függvénykapcsolatokat felírtuk, térbeli diagramban ábrázoltuk.

Az elvégzett két kísérlet analizált eredményei alapján az alábbi következtetéseket tesszük:

- Az I. kísérletsorozatnál mind az Ra értéket az előtolás, míg a CYLt értéket a vasalási járatszám változása befolyásolta legintenzívebben. Mind az Ra és a CYLt esetén a nagyobb előtolás $\left(\mathrm{f}_{2}=0,005 \mathrm{~mm} /\right.$ ford$)$, kisebb erő $\left(\mathrm{F}_{1}=10 \mathrm{~N}\right)$ volt az elönyösebb. Viszont Ra esetében a nagyobb járatszám ( $\mathrm{i}=3$ ), míg a CYLt hengerességi hiba esetén a kisebb járatszám ( $\mathrm{i}=1)$ eredményezte a nagyobb mértékủ javulást;

- A II. kísérletsorozatnál a CYLp és a CYLt paraméternél a vasalási sebesség változtatása, míg a CYLv esetén az elötolás változtatása eredményezte a legintenzívebb változást. Mindhárom hengerességi paraméter (CYLp, CYLv és CYLt) esetén a kisebb vasalási sebesség ( $\mathrm{v}_{1}=15 \mathrm{~m} / \mathrm{min}$ ) és kisebb előtolás ( $\mathrm{f}_{1}=0,001 \mathrm{~mm} /$ ford) alkalmazása volt az előnyösebb. A CYLp és CYLt vonatkozásában a nagyobb vasalóerő $\left(\mathrm{F}_{2}=20 \mathrm{~N}\right)$, míg a CYLv tekintetében a kisebb vasalóerő $\left(\mathrm{F}_{1}=10 \mathrm{~N}\right)$ alkalmazása volt az elönyösebb.

A vasalóerő vonatkozásában a felületi érdességnél alkalmazott paraméter beállítást alátámasztja, hogy az EN AW-2011 jelủ alumínium viszonylag lágy, szakítószilárdsága (280-320 MPa), melyre a nagyobb vasalóerő hatása nem előnyös. A nagyobb járatszám $(i=3)$ előnyös a kisebb vasalás utáni érdesség $(\mathrm{Ra}=0,2516 \mu \mathrm{m})$ elérése szempontjából.

\section{Köszönetnyilvánítás}

„A cikkben ismertetett kutató munka az EFOP-3.6.1-16-2016-00011 jelü „Fiatalodó és Megújuló Egyetem - Innovatív Tudásváros - a Miskolci Egyetem intelligens szakosodást szolgáló intézményi fejlesztése" projekt részeként - a Széchenyi 2020 keretében - az Európai Unió támogatásával, az Európai Szociális Alap társfinanszírozásával valósul meg".

\section{Irodalom}

[1] Scibner, I.A.: Burnishing tool. United States Patent 1171146, Patented Feb. 8 (1916)

[2] Revankar, G.D., Shetty, R., Rao, S.S., Gaitonde, V.N.: Wear resistance enhancement of titanium alloy (Ti-6Al-4V) by ball burnishing process, Journal of Materials Research and Technology 6 (1) (2017) pp.: 13-32 https://doi.org/10.1016/j.jmrt.2016.03.007

[3] Kato, H., Ueki, H., Yamamoto, K., Uasunaga, K.: Wear resistance improvement by nanostructured surface layer produced by burnishing, Material Science Forum 917 (2018) pp.: 231-235 https://doi.org/10.4028/www.scientific.net/MSF.917.231

[4] Krishna, R.M., Koorapati, E.P.: A study of wear resistance of non-ferrous roller burnished components. Int. J. Appl. Manag. Sci. 3 (1) (2012) pp.: 11-24 
[5] Rao, D.S., Hebbar, H.S., Komaraiah, M., Kempaiah, U.N.: Investigation on the effect of ball burnishing parameters on surface roughness and corrosion resistance of HSLA dual-phase steels. East African Journal of Sciences 2(2) (2008) pp.: 164-169 https://doi.org/10.4314/eajsci.v2i2.40377

[6] Hull, E.H., Nerad, A.J.: Irregular diamond burnishing tool. United States patent 2966722, patented Jan, vol. 3, p 1961

[7] Yu, X., Wang, L.: Effect of various parameters on the surface roughness of an aluminium alloy burnished with a spherical surfaced polycrystalline diamond tool, Int. J. Mach. Tools. Manuf. 39 (3) (1999) pp.: 459-469 https://doi.org/10.1016/S0890-6955(98)00033-9

[8] Luo, H., Liu, J., Zhong, Q.: Investigation of the burnishing process with PCD tool on non-ferrous metals, Int. J. Adv. Manuf. Technol. 25 (5-6) (2005) pp.: 454-459 https://doi.org/10.1007/s00170-003-1959-5

[9] Esme, U.: Use of grey based Taguchi method in ball burnishing process for the optimization of surface burnishing and microhardness of AA7075 aluminium alloy, Mater. Technol. 44 (2010) pp.: 129-135

[10] Maximov, J.T., Anchev, A.P., Duncheva, G.V., Ganev, N, Selimov, K.F.: Influence of the process parameters on the surface roughness, micro-hardness, and residual stresses in slide burnishing of high-strength aluminium alloys, Journal of the Brazilian Society of Mechanical Sciences and Engineering. 39(8) (2017) pp.: 3067-3078 https://doi.org/10.1007/s40430-016-0647-y

[11] Varga, G., Ferencsik, V.: Investigation of the influence of different burnishing parameters on shape correctness and residual stresses. IOP Conf. Series: Mater. Sci. Eng. 448: 012016 (2018) https://doi. org/10.1088/1757-899X/448/1/012016

[12] Huuki, J., Laakso, S.V.A.: Integrity of surface finished with ultrasonic burnishing. Proc IMechE Part B: J. Eng. Manuf. 227 (1) (2013) pp.: 45-53 https://doi.org/10.1177/0954405412462805

[13] Korzynski, M., Pacana, A., Cwanek, J.: Fatigue strength of chromium coated elements and possibility of its improvement with slide diamond burnishing, Surf. Coat. Technol. 203: (2009) pp.:1670-1676 https://doi.org/10.1016/j.surfcoat.2008.12.022

[14] Swirad, S.: The surface texture analysis after slide burnishing with cylindrical elements, Wear 271 (2011) pp.: 576-581 https://doi.org/10.1016/j.wear.2010.05.005

[15] Hamadache, H., Zemouri, Z., Laouar, L., Dominiak, S.: Improvement of surface conditions of 36CrNiMo6 steel by ball burnishing process, J. Mech. Sci. Technol. 28 (4) (2014) pp.: 1491-1498 https://doi.org/10.1007/s12206-014-0135-1

[16] Tobola, D., Rusek, P., Czechowski, K., Miller, T., Duda, K.: New indicators of burnished surface evaluation - reasons of application, Metrol. Meas. Syst. 22 (2) (2015) pp.: 263-274 https://doi.org/10.1515/mms-2015-0018

[17] Korzynski, M., Dudek, K., Palczak, A., Kruczek, B., Kocurek, P.: Experimental models and correlations between surface parameters after slide diamond burnishing, Meas. Sci. Rev. 18 (3) (2018) pp.: 123-129 https://doi.org/10.1515/msr-2018-0018

[18] Maximov, J.T., Duncheva, G.V., Anchev, A.P., Ganev, N, Amudjev, I.M., Dunchev, V.P: Effect of slide burnishing method on the surface integrity of AISI 316Ti chromium-nickel steel, Journal of the Brazilian Society of Mechanical Sciences and Engineering, 40 (194) (2018) pp.: 1-14 https://doi.org/10.1007/s40430-018-1135-3

[19] https://www.alumeco.com/aluminium/bars/square-bars/en-aw-2011/10-mm/p/472/8999 (Megtekintés dátuma: 2021.01.07.) 